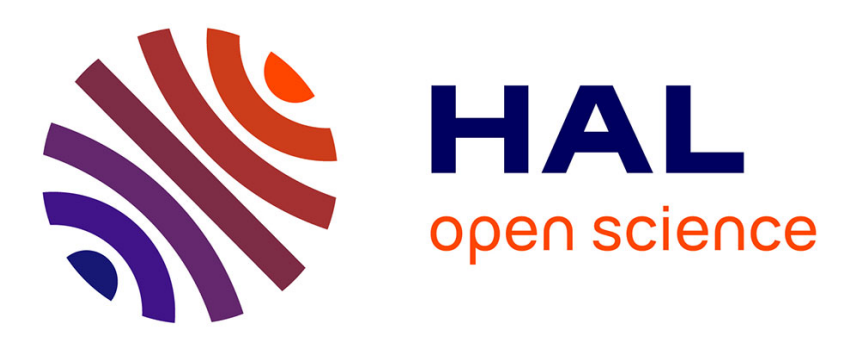

\title{
Synthesis of polyelectrolytes bearing phosphorylcholine Moieties
}

\author{
A. Reisch, J. C. Voegel, G. Decher, P. Schaaf, Philippe J. Mésini
}

\section{To cite this version:}

A. Reisch, J. C. Voegel, G. Decher, P. Schaaf, Philippe J. Mésini. Synthesis of polyelectrolytes bearing phosphorylcholine Moieties. Macromolecular Rapid Communications, 2007, 28 (23), pp.2217-2223. 10.1002/marc.200700510 . hal-00354747

\section{HAL Id: hal-00354747 https://hal.science/hal-00354747}

Submitted on 24 Nov 2020

HAL is a multi-disciplinary open access archive for the deposit and dissemination of scientific research documents, whether they are published or not. The documents may come from teaching and research institutions in France or abroad, or from public or private research centers.
L'archive ouverte pluridisciplinaire HAL, est destinée au dépôt et à la diffusion de documents scientifiques de niveau recherche, publiés ou non, émanant des établissements d'enseignement et de recherche français ou étrangers, des laboratoires publics ou privés. 


\title{
Synthesis of polyelectrolytes bearing phosphorylcholine moieties
}

Andreas Reisch ${ }^{\mathrm{a}}$, Jean-Claude Voegel ${ }^{\mathrm{b}}$, Gero Decher ${ }^{\mathrm{a}}$, Pierre Schaaf ${ }^{\mathrm{a} *}$ and Philippe J. Mésini $^{\text {a* }}$

${ }^{\mathrm{a}}$ Institut Charles Sadron

6 rue Boussingault

67083 Strasbourg Cedex

mesini@ics.u-strasbg.fr

${ }^{\mathrm{b}}$ INSERM U 595

Faculté de Chirurgie Dentaire

67085 Strasbourg, France

\begin{abstract}
We report on the modification of the polyelectrolytes poly(L-glutamic acid) (PGA), poly(acrylic acid) (PAA) and poly(L-lysine) (PLL) with side-groups bearing phosphorylcholine (PC) groups. Two different side-chains were synthesized from monoamino tri or tetraethylene glycol, both with PC group linked to the $\mathrm{OH}$ end: the tertbutyloxycarbonyl protected compounds $\mathrm{BOCNH}(\mathrm{EO}){ }_{\mathrm{n}} \mathrm{PC}(\mathrm{n}=2,3)$ and the succinylated compound $\mathrm{SucNH}(\mathrm{EO})_{3} \mathrm{PC} . \mathrm{BOCNH}(\mathrm{EO})_{\mathrm{n}} \mathrm{PC}$ was deprotected and the resulting amine was condensed with PGA or PAA and $\mathrm{SucNH}(\mathrm{EO})_{3} \mathrm{PC}$ was directly coupled with PLL. Degrees of substitution as high as $80 \%$ were obtained with the described method. These polyelectrolytes are potential candidates to fabricate multilayers with protein repellent properties.
\end{abstract}

\section{Introduction}

The phosphorylcholine group (PC) is a major component of biological membranes and well known for its excellent resistance to protein adsorption and its hemocompatibility. First interest in the chemical base of hemocompatibility arose when Zwaal et al. ${ }^{[1]}$ were able to show that the phospholipids that are predominantly found in the outer leaflet of the 
erythrocyte membrane are non-thrombogenic. Many results show that mainly the electrically neutral, zwitterionic phosphorylcholine head group is responsible for these non-thrombogenic properties and the resistance to protein adsorption. ${ }^{[1-3]}$ This observation has triggered much work to impart protein repellent properties to biomaterials by mimicking the outer layer of erythrocytes through the incorporation of PC..$^{[4-6]}$ Different strategies were followed depending upon the nature of the substrate. Self-assembled monolayers were used on gold ${ }^{[7]}$ and silicon substrates. ${ }^{[8-10]}$ Direct grafting of PC containing polymers on various substrates either by conventional radical polymerization ${ }^{[11]}$ or by surface-initiated $\mathrm{ATRP}^{[12,13]}$ were carried out. Carbon-chain polymers bearing PC side chains, the best known being the polymer based on 2-methacryloyloxyethyl phosphorylcholine (MPC) monomer, were synthesized to create nonfouling coatings for biomaterials. ${ }^{[5,14]}$

Most of these surface modifications are substrate or geometry specific. In contrast, polyelectrolyte multilayers $^{[15]}$ can be fabricated on many different surfaces almost independently of the chemical nature, the size and the shape of the underlying substrate. Polyelectrolyte multilayers are obtained by bringing a substrate alternately in contact with a polyanion and a polycation solution and constitute a very versatile tool to coat and render surfaces biologically active ${ }^{[16,17]}$ or tunable. ${ }^{[18]}$ This can be achieved by incorporation through simple adsorption of active compounds such as anti-inflammatory drugs ${ }^{[19]}$, active peptides ${ }^{[20]}$ or proteins, ${ }^{[21]} \mathrm{DNA}^{[22]}$ or through inclusion of active vesicles. ${ }^{[23]}$ We have recently reviewed the fabrication of biofunctional surfaces using layer-by-layer assembly. ${ }^{[24]}$ Schlenoff at al. ${ }^{[25]}$ already showed that in polyelectrolyte multilayers, when the outer layers bear sulfobetain zwitterionic groups, cellular adhesion is greatly reduced. Polyelectrolytes bearing zwitterionic groups and in particular PC groups thus could constitute a very interesting class of macromolecules to create nonfouling surfaces employing layer-by-layer deposition. This technique would, in addition, allow conferring additional properties to the coatings and thus 
render them multifunctional. A thorough investigation of the development of such films requires however to have access to a whole library of polyelectrolytes.

PC-bearing polymers are usually obtained by polymerization of PC-based monomers. ${ }^{[26,27]}$ Such an approach can, however, hardly be generalized to a large class of polyelectrolytes, each case necessitating a different reaction scheme. Following the pioneering work of Winnik $^{[28,29]}$ et al., we propose a route based on the modification of existing polymers with side groups bearing PC moieties. Winnik et al. reported on the modification of amino polyelectrolytes like chitosan by reductive amination of PC-CHO. This approach, even if it proceeds in high yield, can only be applied to polyamines. For other polymers, the amine groups have to be introduced either by copolymerization with an amino-monomer or by a modification of the respective polyelectrolyte. In this article we propose an alternative route that is based on the synthesis of the heterobifunctional oligo(ethylene oxide) $\mathrm{H}_{2} \mathrm{~N}(\mathrm{EO})_{\mathrm{n}} \mathrm{PC}$, (EO : ethylene oxide). These compounds can be directly coupled to the carboxylic groups of a polyelectrolyte backbone via a carbodiimide coupling or coupled to the amine groups of polyamines via an additional transformation into a succinylated derivative $\operatorname{SucHN}(\mathrm{EO})_{\mathrm{n}} \mathrm{PC}$. The synthesized polyelectrolytes are represented on scheme 1. Our synthetic strategy is thus applicable to a very broad range of polyelectrolytes and can be generalized to other spacers than $(\mathrm{EO})_{\mathrm{n}}$ oligomers. However, we chose the oligoethyleneoxide spacers because of their known hydrophilicity and biocompatibility. ${ }^{[30]}$ Moreover, it was also shown that the introduction of two EO units between the methacrylate and the PC groups in MPC butylmethacrylate copolymers increased only slightly the fibrinogen adsorption, compared to the parent MPC-BMA copolymer without spacer and that platelet adhesion is effectively prevented for about $30 \%$ of PC units in both cases. ${ }^{[31,32]}$. 


\section{Experimental Part}

\section{Materials}

Organic solvents were purchased in analytical grade quality from Acros, Aldrich, Fluka, Merck, Riedel-de-Haën and VWR. They were used as received for chromatography. Ethyl acetate, chloroform and acetonitrile were distilled under inert atmosphere with the usual drying agents prior to their use as reaction solvents. Millipore water was used for all the experiments.

Triethylene glycol mono-amine (Molecular Biosciences, 99.5\%) and tetraethylene glycol mono-amine (Molecular Biosciences, 99\%) were transformed into the BOC derivative by known procedures. ${ }^{[33,34]}$ Choline tosylate $(\mathrm{ABCR},>97 \%)$, Di-tert-butyl dicarbonate $\left(\mathrm{Boc}_{2} \mathrm{O}\right.$, Fluka, $\geq 98 \%), \mathrm{N}^{\prime}$-(3-dimethylaminopropyl)-N-ethyl carbodiimide hydrochloride (EDCI, Fluka, $\geq 98 \%$ ), $\mathrm{POCl}_{3}$ (Acros, 99\%), pyridine (Fluka, absolute over molar sieve), succinic anhydride (Acros, $\geq 99 \%$ ), trimethylamine (Fluka, > 99\%), 1-hydroxybenzotriazole hydrate (HOBt, Fluka, $\geq$ 99\%), poly-L-glutamic acid sodium salt (PGA, Sigma, MW 50-100,000), poly-L-lysine hydro bromide (PLL, Sigma, MW 25,500), poly(acrylic acid) (PAA, Aldrich, 35 wt.\% in water, Mw 100,000), 1,2-dibutyroyl-sn-glycero-3-phosphocholine (04:0 PC, Avanti Polar Lipids) were used as received.

\section{NMR measurements}

NMR spectra were recorded on a Bruker Avance 400 operating at $400 \mathrm{MHz}$ for ${ }^{1} \mathrm{H}$ and 100 MHz for ${ }^{13} \mathrm{C} .{ }^{1} \mathrm{H}-{ }^{1} \mathrm{H}$ and ${ }^{1} \mathrm{H}_{-}{ }^{13} \mathrm{C}$ shift correlated spectra were recorded using the standard pulse sequences provided by Bruker. The degree of substitution (DS) was determined from the ratios of integrals of the ${ }^{1} \mathrm{H}$-signals of the protons belonging to the spacers and PC groups to the integrals of the signals of the repeat unit. In the case of PGA(EO) ${ }_{3} \mathrm{PC}$ for example, the calculation was based on the signals at 4.05 (d), 3.78-3.67 (e, f, g, b), 3.63 (h), 3.40 (i) or 3.24 
(a) ppm (the letters correspond to the labelling of figure 3B). The values calculated from each of these signals were found equal within an error of $3 \%$.

\section{FTIR measurements}

The FTIR spectra were recorded on a Bruker Vertex 70 spectrometer. The ATR-mode was used for the small molecules. For the determination of DS, the transmission spectra of the polymers were measured in $\mathrm{D}_{2} \mathrm{O}$ buffered with Trizma Base $(0.12 \mathrm{M}, \mathrm{pH}$ adjusted to 9.4 with DCl) using Specac ${ }^{\mathrm{TM}}$ cells purchased from Eurolabo, with ZnSe windows and an optical path length of $0.1 \mathrm{~mm}$. The bands at 1564 and $1405 \mathrm{~cm}^{-1}\left(v_{\mathrm{as}}\right.$ and $\left.v_{\mathrm{s}} \mathrm{COO}^{-}\right)$were used to determine the conc. $\left[\mathrm{COO}^{-}\right]$from a calibration curve established with PGA. Both bands gave the same results. The bands at 1087 and $971 \mathrm{~cm}^{-1}\left(v_{\mathrm{s}} \mathrm{PO}_{2}^{-}\right.$and $\left.v_{\text {as }}\left(\mathrm{CH}_{3}\right)_{3} \mathrm{~N}^{+}\right)$were used to determine [PC], the phosphorylcholine conc. from a calibration curve established with 04:0 PC. The degree of substitution DS was calculated according to : $\mathrm{DS}=[\mathrm{PC}] /\left([\mathrm{PC}]+\left[\mathrm{COO}^{-}\right]\right)$.

\section{SEC measurements}

The SEC experiments have been performed with an Agilent 1100 pumping unit and three sequential columns Shodex OH (1803 HQ, 1804 HQ, 1806 HQ), a differential refractometer Optilab rEX (from Wyatt Techn.) and a Dawn Heleos multiangle light scattering detector (from Wyatt Techn.). The solvent was a solution of $\mathrm{NaNO}_{3}(0.1 \mathrm{M})$ and $\mathrm{NaN}_{3}(5 \mathrm{mM})$ in tridistilled water. Volumes of $100 \mu \mathrm{L}$ of solution at $5 \mathrm{mg} / \mathrm{mL}$ were injected and eluted at 0.5 $\mathrm{mL} / \mathrm{min}$

Synthesis of the side-chains

\section{[2-(2-N-tert-Butoxycarbonylamino-ethoxy)-ethoxy]-ethylphosphorylcholine}

$\left(\mathbf{B O C N H}(\mathbf{E O})_{3} \mathbf{P C}\right):$ To a solution of $\mathrm{POCl}_{3}\left(3.35 \mathrm{~g}, 21.8 \mathrm{mmol}, 1.3\right.$ equiv.) in $\mathrm{CHCl}_{3}(20$ $\mathrm{mL})$, a solution of $\mathrm{BOCNH}(\mathrm{EO})_{3} \mathrm{H}\left(4.16 \mathrm{~g}, 16.7 \mathrm{mmol}, 1\right.$ equiv.) and $\mathrm{NEt}_{3}(12.6 \mathrm{~mL}, 90.4$ mmol, 5.4 equiv.) in $\mathrm{CHCl}_{3}(100 \mathrm{~mL})$ was added dropwise at $0{ }^{\circ} \mathrm{C}$ and the mixture was stirred for $2 \mathrm{~h}$ at $25^{\circ} \mathrm{C}$. The mixture was cooled at $0^{\circ} \mathrm{C}$ and choline tosylate $(10.39 \mathrm{~g}, 37.7 \mathrm{mmol}, 2.26$ 
equiv.) and pyridine $(15.4 \mathrm{~mL})$ were added. The reaction mixture was stirred for an additional $12 \mathrm{~h}$ at room temperature and water $(6.2 \mathrm{~mL})$ was added. After $45 \mathrm{~min}$ the solvents were evaporated under reduced pressure and a red solid residue was obtained. Chromatography $\left(\mathrm{SiO}_{2}, 25-35 \%\right.$ water-acetone gradient elution) afforded $\mathrm{BOCNH}(\mathrm{EO})_{3} \mathrm{PC}$ as a white deliquescent solid (3.05 g, $50 \%$ yield): ${ }^{1} \mathrm{H}$ NMR $\left(\mathrm{D}_{2} \mathrm{O}, 400 \mathrm{MHz}\right): \delta=4.34$ (br m, $2 \mathrm{H}$, $\mathrm{POCH}_{2} \mathrm{CH}_{2} \mathrm{~N}$ ), $4.05\left(\right.$ br m, $\left.2 \mathrm{H}, \mathrm{POCH}_{2} \mathrm{CH}_{2} \mathrm{O}\right), 3.76-3.68\left(\mathrm{~m}, 8 \mathrm{H}, \mathrm{CH}_{2} \mathrm{OCH}_{2} \mathrm{CH}_{2} \mathrm{O}\right.$, $\left.\mathrm{CH}_{2} \mathrm{~N}\left(\mathrm{CH}_{3}\right)_{3}\right), 3.61\left(\mathrm{t}, 2 \mathrm{H}, J=5.36 \mathrm{~Hz}, \mathrm{OCH}_{2} \mathrm{CH}_{2} \mathrm{~N}\right), 3.28\left(\mathrm{t}, 2 \mathrm{H}, J=5.36 \mathrm{~Hz}, \mathrm{CH}_{2} \mathrm{~N}\right), 3.24$ (s, 9H, N(CH3)3), $1.44\left(\mathrm{~s}, 9 \mathrm{H}, \mathrm{C}\left(\mathrm{CH}_{3}\right)_{3}\right) ;{ }^{13} \mathrm{C}-\mathrm{NMR}\left(\mathrm{D}_{2} \mathrm{O}, 100 \mathrm{MHz}\right): \delta=158.9(\mathrm{CO}), 81.7$ $\left(C\left(\mathrm{CH}_{3}\right)_{3}\right), 70.8\left(\mathrm{~d}, J=7.7 \mathrm{~Hz}, \mathrm{OCH}_{2} \mathrm{CH}_{2} \mathrm{OP}\right), 70.4,70.1\left(\mathrm{OCH}_{2} \mathrm{CH}_{2}\right), 66.7(\mathrm{~m}$, $\left.\mathrm{CH}_{2} \mathrm{~N}\left(\mathrm{CH}_{3}\right)_{3}\right), 65.5\left(\mathrm{~d}, J=5.8 \mathrm{~Hz}, \mathrm{POCH}_{2} \mathrm{CH}_{2} \mathrm{O}\right), 60.1\left(\mathrm{~d}, J=4.8 \mathrm{~Hz}, \mathrm{POCH}_{2} \mathrm{CH}_{2} \mathrm{~N}\right), 54.6$ $\left(\mathrm{t}, J=3.7 \mathrm{~Hz}, \mathrm{~N}\left(\mathrm{CH}_{3}\right)_{3}\right), 40.3\left(\mathrm{CH}_{2} \mathrm{~N}\right), 28.4\left(\mathrm{C}\left(\mathrm{CH}_{3}\right)_{3}\right)$; IR (ATR) $v_{\max }: 3355$ (sh) and 3223 (vNH), $2975\left(v_{\text {as }} \mathrm{CH}_{3}\right), 2937\left(v_{\text {as }} \mathrm{CH}_{2}\right), 2878\left(v_{\mathrm{s}} \mathrm{CH}_{2}\right), 1696$ (amide I), 1525 (amide II), 1484 $\left(\delta_{\text {as }}\left(\mathrm{CH}_{3}\right)_{3} \mathrm{~N}^{+}\right), 1458 ; 1391$ and $1365\left(\delta \mathrm{CH}_{3}\right), 1247,1172,1089\left(v_{\mathrm{s}} \mathrm{PO}_{2}{ }^{-}\right), 1058,968(\mathrm{sh})$ and $\left.954\left(v_{\text {as }} \mathrm{CH}_{3}\right)_{3} \mathrm{~N}^{+}\right), 920,865,777 \mathrm{~cm}^{-1}$. HRMS (ESI+) : m/z $415.2216\left(\mathrm{MH}^{+}, \mathrm{C}_{16} \mathrm{H}_{35} \mathrm{~N}_{2} \mathrm{O}_{8} \mathrm{P}\right.$ requires 415.2203), 437.2036 $\left(\mathrm{MNa}^{+}, \mathrm{C}_{16} \mathrm{H}_{35} \mathrm{~N}_{2} \mathrm{O}_{8} \mathrm{P}\right.$ requires 437.2029).

$\left(\mathbf{B O C N H}(\mathbf{E O})_{4} \mathbf{P C}\right)$ was synthesized according to the same protocol (see supp. Info for characterization)

\section{2-[2-(2-N-succinylamino-ethoxy)-ethoxy]-ethylphosphorylcholine $\left(\operatorname{SucNH}(\mathrm{EO}){ }_{3} \mathrm{PC}\right)$ :}

BOCNH(EO) $)_{3} \mathrm{PC}(2.53 \mathrm{~g}, 6.10 \mathrm{mmol}, 1$ equiv.) was mixed with aq. $\mathrm{HCl}(2.5 \mathrm{M}, 12 \mathrm{~mL})$ and the mixture stirred at $25{ }^{\circ} \mathrm{C}$ during $90 \mathrm{~min}$. The solution was evaporated under vacuum and dissolved in water $(4.5 \mathrm{~mL})$. The $\mathrm{pH}$ was adjusted to 9 by addition of $2 \mathrm{M}$ aq. $\mathrm{NaOH}$ and a solution of succinic anhydride (1.16 g, $11.60 \mathrm{mmol}, 1.9$ equiv.) in DMSO (3 mL) was added at once and the $\mathrm{pH}$ readjusted to 9.5 . The reaction mixture was stirred for $24 \mathrm{~h}$ at $25{ }^{\circ} \mathrm{C}$, a second batch of succinic anhydride $(2.25 \mathrm{~g}, 22.50 \mathrm{mmol}, 3.7$ equiv.) in DMSO (6 mL) was added and the $\mathrm{pH}$ was readjusted to 9.5 . A third batch of succinic anhydride $(1.03 \mathrm{~g}, 10.30$ 
mmol, 1.7 equiv.) in DMSO (3 mL) was added after 24h. The reaction mixture was stirred for an additional $24 \mathrm{~h}$ at $25^{\circ} \mathrm{C}$. It was precipitated in $\mathrm{EtOH}(400 \mathrm{~mL})$. The precipitate was filtered off and the filtrate was evaporated under vacuum. The obtained solid was redissolved in $\mathrm{MeOH}(10 \mathrm{~mL})$ and the minimal amount of water to solubilize it (ca $1 \mathrm{~mL})$ and mixed with diethyl ether $(100 \mathrm{~mL})$. The organic phase was removed by decantation to yield a paste containing water and the crude product. Chromatography of this residue $\left(\mathrm{SiO}_{2}, 25-33 \%\right.$ water-acetone gradient eluent) afforded $\mathrm{SucNH}(\mathrm{EO})_{3} \mathrm{PC}$ as a white solid (1.59 g, yield 63\%) : ${ }^{1} \mathrm{H}$ NMR $\left(\mathrm{D}_{2} \mathrm{O}, 400 \mathrm{MHz}\right): \delta=4.32\left(\right.$ br $\left.\mathrm{m}, 2 \mathrm{H}, \mathrm{POCH}_{2} \mathrm{CH}_{2} \mathrm{~N}\right), 4.04($ br $\mathrm{m}, 2 \mathrm{H}$,

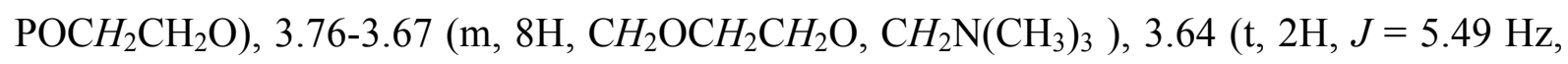
$\left.\mathrm{OCH}_{2} \mathrm{CH}_{2} \mathrm{NHCO}\right), 3.39\left(\mathrm{t}, 2 \mathrm{H}, J=5.42 \mathrm{~Hz}, \mathrm{CH}_{2} \mathrm{NHCO}\right), 3.23\left(\mathrm{~s}, 9 \mathrm{H}, \mathrm{N}\left(\mathrm{CH}_{3}\right)_{3}\right), 2.47$ (m, $\left.4 \mathrm{H}, \mathrm{COCH}_{2} \mathrm{CH}_{2} \mathrm{COO}\right) .{ }^{13} \mathrm{C}-\mathrm{NMR}\left(\mathrm{D}_{2} \mathrm{O}, 100 \mathrm{MHz}\right): \delta=181.5(\mathrm{CO}), 176.6(\mathrm{CO}), 70.8(\mathrm{~d}, J=$

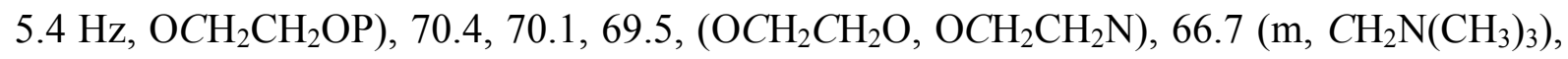
$65.6\left(\mathrm{~d}, J=5.4 \mathrm{~Hz}, \mathrm{POCH}_{2} \mathrm{CH}_{2} \mathrm{O}\right), 60.1\left(\mathrm{~d}, J=4.9 \mathrm{~Hz}, \mathrm{POCH}_{2} \mathrm{CH}_{2} \mathrm{~N}\right), 54.7(\mathrm{t}, J=3.7 \mathrm{~Hz}$, $\left.\mathrm{N}\left(\mathrm{CH}_{3}\right)_{3}\right), 39.6\left(\mathrm{CH}_{2} \mathrm{~N}\right), 33.6\left(\mathrm{CH}_{2} \mathrm{CO}\right), 33.0\left(\mathrm{CH}_{2} \mathrm{CO}\right)$. IR (ATR) v $v_{\max }: 3385(v \mathrm{COOH})$, $3297(v \mathrm{NH}), 3031,2928\left(v_{\text {as }} \mathrm{CH}_{2}\right), 2883\left(v_{\text {as }} \mathrm{CH}_{2}\right), 2479 ; 2402,1639$ (amide I); 1573, 1470, $1398,1356,1236,1133,1088\left(v_{\mathrm{s}} \mathrm{PO}_{2}^{-}\right), 1057,954\left(v_{\text {as }}\left(\mathrm{CH}_{3}\right)_{3} \mathrm{~N}^{+}\right), 924,877,787,748,638$ $\mathrm{cm}^{-1}$.

HRMS (ESI+) : $421.1890 \mathrm{~m} / \mathrm{z}\left(\mathrm{MLi}^{+}\right.$, requires 421.1922).

\section{Coupling reactions.}

The polymers were modified according to the procedure exemplified here by the synthesis of PGA(EO) $)_{3}$ PC 35 and PLLSuc(EO) $)_{3}$ PC 35.

PGA(EO) $)_{3}$ PC 35 : BOCNH(EO) $)_{3} \mathrm{H}(220 \mathrm{mg}, 0.53 \mathrm{mmol}, 0.40$ equiv. $)$ was mixed with aq. $\mathrm{HCl}(6 \mathrm{~mL}, 2.5 \mathrm{M})$ and stirred at $25{ }^{\circ} \mathrm{C}$ for $90 \mathrm{~min}$. The mixture was dried under vacuum. The residue was mixed with PGA (200 mg, $1.32 \mathrm{mmol}$ of glutamyl units) and water (1.5 mL). 
HOBt (180 mg, $1.32 \mathrm{mmol}$, lequiv.) was dissolved in water $(1.5 \mathrm{~mL})$ and the minimal amount of $\mathrm{NEt}_{3}$ and added to the reaction mixture. The $\mathrm{pH}$ was adjusted with $\mathrm{HCl}$ and $\mathrm{NEt}_{3}$ between 4.7 and 5.0 and EDCI (190 mg, $1.22 \mathrm{mmol}, 0.93$ equiv.) was added at $0^{\circ} \mathrm{C}$. The reaction mixture was stirred for $24 \mathrm{~h}$ at $25^{\circ} \mathrm{C}$ and dialyzed with a cellulose ester membrane (MWCO 5000) against $1 \mathrm{M}$ aq. $\mathrm{NaCl}, 0.5 \mathrm{M}$ aq $\mathrm{NaCl}$ and finally Millipore water during 3 days. Lyophilization of the solution afforded $\mathrm{PGA}(\mathrm{EO})_{3} \mathrm{PC} 35$ as a white solid (250 $\mathrm{mg}$, yield 81\%). See Figure 3A, 3B and 4 for characteristic peaks in ${ }^{1} \mathrm{H}$ NMR and IR. Full spectroscopic data is given in suppl. info.

PLLSuc(EO) $)_{3}$ PC 35: PLL (61 mg, $0.29 \mathrm{mmol}$ of lysine units) and sucNH(EO) $)_{3}$ PC (48 mg, $0.12 \mathrm{mmol}, 0.41$ equiv. $)$ were dissolved in water $(1.5 \mathrm{~mL})$. HOBt $(0.040 \mathrm{~g}, 0.30 \mathrm{mmol}, 1.03$ equiv.) dissolved in slightly basic water $(0.7 \mathrm{~mL})$ was added. The $\mathrm{pH}$ was adjusted between 4.7 and 5.0 by the addition of $\mathrm{HCl}$ and $\mathrm{NaOH}$ aq. solutions (1M). EDCI (43 mg, $0.28 \mathrm{mmol}$, 0.97 equiv.) was added to the reaction mixture at $0^{\circ} \mathrm{C}$. The reaction mixture was stirred for 24 h at $25{ }^{\circ} \mathrm{C}$. The $\mathrm{pH}$ was maintained with the $\mathrm{HCl}$ and $\mathrm{NaOH}$ solutions. The reaction mixture was dialyzed with a cellulose ester membrane (MWCO 5000) against $1 \mathrm{M}$ aq. $\mathrm{NaCl}, 0.5 \mathrm{M}$ aq. $\mathrm{NaCl}$ and finally Millipore water for 3 days. One obtains $78 \mathrm{mg}$ of a white powder after lyophilization (yield 74\%). See Figure 3C, 3D for characteristic peaks in ${ }^{1} \mathrm{H}$ NMR. Full spectroscopic data is given in suppl. info.

\section{Results and Discussion}

The synthesized polymers are described on figure 1 . The overall synthetic scheme (figure 2) consists in synthesizing first the side-groups bearing PC at one end and an amine or acid group at the other end, then coupling them to the polymer. The lateral substituents were

synthesized (scheme 2) by the method introduced by Brockerhof, ${ }^{[35,36]}$ which consists in the 
sequential reaction of $\mathrm{POCl}_{3}$ with two different alcohols. First $\mathrm{POCl}_{3}$ is reacted with $\mathrm{BOCNH}(\mathrm{EO})_{\mathrm{n}} \mathrm{H}$ in the presence of $\mathrm{NEt}_{3}$. Then, reaction in situ of the resulting dichlorophosphate with choline tosylate in the presence of pyridine, followed by hydrolysis affords the desired compound in good yield (50\%). The nature of the base used for the second step is very important : when $\mathrm{NEt}_{3}$ is used instead of pyridine, the yield is less than 5 $\%$, probably because pyridine increases the solubility of the choline salt in the reaction mixture.

The compounds $\mathrm{BOCNH}(\mathrm{EO})_{\mathrm{n}} \mathrm{PC}$ obtained by this method can be purified by flash chromatography on silica gel with water-acetone eluent, which allows obtaining the pure compounds at the scale of the gram (NMR spectra given in figure 3A). For the coupling step, $\mathrm{BOCNH}(\mathrm{EO})_{\mathrm{n}} \mathrm{PC}$ is deprotected quantitatively by acidic treatment $(\mathrm{HCl} 2.5 \mathrm{M})$. The resulting amine $\mathrm{H}_{2} \mathrm{~N}(\mathrm{EO})_{\mathrm{n}} \mathrm{PC}$ is obtained in the form of its ammonium chloride. It is not isolated but coupled in situ with PGA or PAA in water, at $\mathrm{pH}$ between 4.7 and 5.0, with an excess of EDCI and HOBt as auxiliary agent. The resulting polyelectrolyte is purified by dialysis against $\mathrm{NaCl}$ first and water then.

The same coupling conditions could be implemented to the coupling of PLL. For this purpose, $\mathrm{H}_{2} \mathrm{~N}(\mathrm{EO})_{3} \mathrm{PC}$ was transformed in the succinylated derivative $\operatorname{SucHN}(\mathrm{EO})_{3} \mathrm{PC}$. This was achieved simply by the deprotection of the amino group followed by the reaction with succinyle anydride in large excess. As expected the competing hydrolysis of the succinyle anhydride occurs, but the formed byproducts do not hamper the purification steps, and SucNH(EO) $)_{3}$ PC could be obtained in good purity. Its coupling to PLL and the following purification steps proceeded the same way as with the PGA.

All the polymers obtained were very hygroscopic and deliquescent at air. However, except water no other impurities were observed. All final polymers gave very clean and well resolved NMR spectra (figure 3A and 3C), The spectra were interpretated by a combined 
analysis of ${ }^{1} \mathrm{H},{ }^{13} \mathrm{C},{ }^{1} \mathrm{H}-{ }^{1} \mathrm{H}$ shift correlated (COSY) and ${ }^{1} \mathrm{H}_{-}{ }^{13} \mathrm{C}$ shift correlated spectra (Suppl. info., figure S2a, S2b). The assignments of the signals are given on figure 3 . They are coherent with the findings in the litterature ${ }^{[29,37,38]}$ and with the structure of the polymers. For PGA(EO) $)_{3} \mathrm{PC}$, the signals of the PC and spacer groups are found at 4.34 (c), 4.05 (d), 3.78-3.67 (e-g, b), $3.63(\mathrm{~h})$ and $3.23 \mathrm{ppm}(\mathrm{a})$ (the letters refer to the indexation given in figure $3 \mathrm{~B})$. In the the non-coupled $\mathrm{BOCNH}(\mathrm{EO})_{3} \mathrm{PC}$, the same protons give signals at similar shifts. But the triplet at 3.40 corresponding to the protons (i) is shifted downfield compared to the same protons in the starting BOC derivative (at 3.29); the new shift is coherent with the formation of an amide. This proves the effective coupling of the PC containing lateral groups. Similar conclusions were obtained for the other polymers. The IR spectra (figure 4) of the polymers also exhibit the characteristic bands of PC groups: The band at $1087 \mathrm{~cm}^{-1}$ can clearly be assigned to the $\mathrm{PO}_{2}^{-}$symmetric stretching $\left(\nu_{\mathrm{s}}\left(\mathrm{PO}_{2}^{-}\right)\right)$, the one at $967 \mathrm{~cm}^{-1}$ to the $\mathrm{N}+-$ $\left(\mathrm{CH}_{3}\right)_{3}$ antisymmetric stretching, $\left(\mathrm{v}_{\mathrm{as}}\left(\mathrm{N}-\mathrm{CH}_{3}\right)\right)$, the $930 \mathrm{~cm}^{-1}$ band to the $\mathrm{C}-\mathrm{N}+-\left(\mathrm{CH}_{3}\right)_{3}$ symetric stretching, $\left(v_{\mathrm{s}}\left(\mathrm{N}-\mathrm{CH}_{3}\right)\right)$, and the one at $802 \mathrm{~cm}^{-1}$ to the $\mathrm{P}-(\mathrm{OC})_{2}$ antisymmetric stretching $\left(v_{\text {as }}\left(\mathrm{P}-(\mathrm{OC})_{2}\right)\right)$ vibrations. ${ }^{[29,39]}$ No chloride was detected by ICP-MS in the final compounds.

The degree of substitution (DS) can be calculated from the NMR spectra with a satisfactory accuracy. IR spectroscopy was used to confirm these DS. The $\mathrm{NCH}_{3}$ and the $\mathrm{COO}^{-}$stretching bands were measured simultaneoulsy for each sample and used to calculate the choline and the $\mathrm{COO}^{-}$concentrations respectively. This double measurement enables the calculation of the DS independently from the water content of the polymers and avoids the accurate determination of the concentration in these hygroscopic polymers. The DS calculated from NMR and IR (Table 1) are in good agreement. The efficiency of the coupling reaction is above $85 \%$ for $\mathrm{H}_{2} \mathrm{~N}(\mathrm{EO})_{3} \mathrm{PC}$ and $\mathrm{SucNH}(\mathrm{EO})_{3} \mathrm{PC}$ and $45 \%$ for $\mathrm{H}_{2} \mathrm{~N}(\mathrm{EO})_{4} \mathrm{PC}$. It is similar for PLL and PGA, but surprisingly, PAA and $\mathrm{H}_{2} \mathrm{~N}(\mathrm{EO})_{3} \mathrm{PC}$ couple with nearly quantitative yield. 
A DS greater than $80 \%$ could be obtained with a sufficient excess of amine with a good efficiency $(60 \%)$.

The masses of the modified PGA were determined by SEC coupled with MALLS. The measured masses $\mathrm{Mw}$ for the starting PGA, PGA(EO) $)_{4} \mathrm{PC} 35$ and $\mathrm{PGA}(\mathrm{EO})_{4} \mathrm{PC} 16$ are 65, 60 and $55 \mathrm{kDa}$ respectively, which shows that a limited mass diminution occurs during the coupling reaction. The resulting mass is still accptable for layer-by-layer deposition. Two groups have shown ${ }^{[40,41]}$ that carbodiimides may cleave the main chain of poly(- $\alpha$-glutamic acid) or poly(- $\gamma$-glutamic acid) resulting in 10 to 50 times shorter chain fragments. The chain cleavage was attributed to side reactions that occur with the O-acylurea intermediates formed from the addition of the acid side goup to the carbodiimide. One of these groups ${ }^{[40]}$ had not used HOBt. This auxiliary nucleophile reduces the concentration of the O-acylurea and the

side reactions due to this species. However, the other group ${ }^{[41]}$ had used a 20 fold excess of HOBt and still observed cleavage in a large extent. The reaction conditions described herein are different since we have used a 100 times larger concentration in acid and a 9 times larger concentration in HOBt compared with the referenced work. These higher concentrations induce a lower ratio of the concentration in O-acylurea and amines and explain why the chain cleavage is limited. This high concentration also proved beneficial to reach high substitution levels.

\section{Conclusion}

Weak polyelectrolytes were functionalized with phosphorylcholine connected through oligo(ethylenoxide) to the main chain. First, side-chains with either acid or amine end groups were synthesized in a good purity level and at the scale of the gram, from the same pool of intermediates. Then these side groups were coupled by standard methods with the polymers. The method allows the functionalization of a wide range of polyacids or polyamines. The 
coupling reactions proceed with a high efficiency and allow degrees of substitution up to 80 $\%$.

Both the scale of the preparations and the purity levels attained make these polymers suitable to explore their physicochemical behavior in solution and serve as a library to investigate new types of polyelectrolyte multilayers.

\section{Acknowledgements}

This work is supported by a fellowship from the Région Alsace. We thank Anne Boos for the ICP-MS measurements and A. Rameau and C. Foussat for the SEC/MALLS measurements.

\section{Supplementary information}

Full characterization of $\mathrm{BOCHN}(\mathrm{EO})_{3} \mathrm{PC}$. NMR datas of $\mathrm{PGA}(\mathrm{EO})_{4} \mathrm{PC} 16, \mathrm{PAA}(\mathrm{EO})_{3} \mathrm{PC} 25$.

\section{References}

[1] R. F. A. Zwaal, P. Comfurius, L. L. M. Van Deenen, Nature 1977, 268, 358.

[2] D. Chapman, Langmuir 1993, 9, 39.

[3] A. D. Bangham, Nature 1961, 192, 1197.

[4] K. Ishihara, H. Oshida, Y. Endo, T. Ueda, A. Watanabe, N. Nakabayashi, J. Biomed. Mater. Res. 1992, 26, 1543.

[5] A. L. Lewis, Colloids Surf., B 2000, 18, 261.

[6] W. Feng, S. Zhu, K. Ishihara, J. L. Brash, Biointerphases 2006, 1, 50

[7] S. Chen, J. Zheng, L. Li, S. Jiang, J. Am. Chem. Soc. 2005, 127, 14473.

[8] J. A. Hayward, D. Chapman, Biomaterials 1984, 5, 135.

[9] K. G. Marra, T. M. Winger, S. R. Hanson, E. L. Chaikof, Macromolecules 1997, 30, 6483.

[10] K. G. Marra, D. D. A. Kidani, E. L. Chaikof, Langmuir 1997, 13, 5697.

[11] T. Moro, Y. Takatori, K. Ishihara, T. Konno, Y. Takigawa, T. Matsushita, U. I. Chung, K. Nakamura, H. Kawaguchi, Nat. Mater. 2004, 3, 829.

[12] E. J. Lobb, I. Ma, N. C. Billingham, S. P. Armes, A. L. Lewis, J. Am. Chem. Soc. 2001, 123, 7913.

[13] W. Feng, S. Zhu, K. Ishihara, J. L. Brash, Langmuir 2005, 21, 5980.

[14] K. Ishihara, Sci. Technol. Adv. Mater. 2000, 1, 131.

[15] G. Decher, Science 1997, 277, 1232.

[16] B. Thierry, F. M. Winnik, Y. Merhi, M. Tabrizian, J. Am. Chem. Soc. 2003, 125, 7494.

[17] Z. Tang, Y. Wang, P. Podsiadlo, N. A. Kotov, Adv. Mater. 2006, 18, 3203.

[18] E. Vazquez, D. M. Dewitt, P. T. Hammond, D. M. Lynn, J. Am. Chem. Soc. 2002, 124, 13992.

[19] N. Benkirane-Jessel, P. Schwinté, P. Falvey, R. Darcy, Y. Haïkel, P. Schaaf, J.-C. Voegel, J. Ogier, Adv. Funct. Mater. 2004, 14, 174. 
[20] J. Chluba, J. C. Voegel, G. Decher, P. Erbacher, P. Schaaf, J. Ogier, Biomacromolecules 2001, 2, 800.

[21] N. Jessel, F. Atalar, P. Lavalle, J. Mutterer, G. Decher, P. Schaaf, J.-C. Voegel, J. Ogier, Adv. Mat. 2003, 15, 692.

[22] N. Jessel, M. Oulad-Abdelghani, F. Meyer, P. Lavalle, Y. Haikel, P. Schaaf, J. C. Voegel, Proc. Natl. Acad. Sci. USA 2006, 103, 8618.

[23] M. Michel, Y. Arntz, G. Fleith, J. Toquant, Y. Haikel, J. C. Voegel, P. Schaaf, V. Ball, Langmuir 2006, 22, 2358.

[24] N. Benkirane-Jessel, P. Lavalle, V. Ball, J. Ogier, B. Senger, C. Picart, P. Schaaf, J.-C. Voegel, G. Decher, in Macromolecular Engineering, Vol. 2 (Eds.: Y. Gnanou, L. Leibler, K. Matyiaszwski), Wiley VCH, 2007, pp. 1249.

[25] D. S. Salloum, S. G. Olenych, T. C. S. Keller, J. B. Schlenoff, Biomacromolecules 2005, 6, 161.

[26] T. Nakaya, Y. Li, J. Prog. Polym. Sci. 1999, 24, 143.

[27] E. J. Lobb, I. Ma, N. C. Billingham, A. L. Lewis, S. P. Armes, J. Am. Chem. Soc. 2001, 123, 7913.

[28] K. Miyazawa, F. M. Winnik, Macromolecules 2002, 35, 9536.

[29] M. J. Tiera, X. P. Qiu, S. Bechaouch, Q. Shi, J. C. Fernandes, F. M. Winnik, Biomacromolecules 2006, 7, 3151.

[30] J. M. Harris, Poly(ethylene glycol) chemistry. Biotechnical and Biomedical Applications, Plenum Press, New York, 1992.

[31] Y. Iwasaki, K. Kurita, K. Ishihara, N. Nakabayashi, J. Biomater. Sci. Polym. Ed. 1996, $8,151$.

[32] K. Ishihara, A. Fujiike, Y. Iwasaki, K. Kurita, N. Nakabayashi, J. Polym. Sci., Part A: Polym. Chem. 1996, 34, 199.

[33] C. J. T. Hoes, M. Ankone, J. Grootoonk, J. Feijen, E. van der Struik, A. van Doornmalen, D. Pham, A. de Man, A. van Ettekoven, et al., Journal of Controlled Release 1996, 38, 245.

[34] R. B. Greenwald, Y. H. Choe, C. D. Conover, K. Shum, D. Wu, M. Royzen, J. Med. Chem. 2000, 43, 475.

[35] H. Brockerhoff, N. K. N. Ayengar, Lipids 1979, 14, 88.

[36] J. Lindberg, J. Ekeroth, P. Konradsson, J. Org. Chem. 2002, 67, 194.

[37] V. Govindaraju, K. Young, A. A. Maudsley, NMR Biomed 2000, 13, 129.

[38] C. J. Lacey, L. M. Loew, The Journal of Organic Chemistry 1983, 48, 5214.

[39] H. Binder, A. Anikin, B. Kohlstrunk, G. Klose, J. Phys. Chem. B 1997, 101, 6618.

[40] Y. Paterson, S. J. Leach, Biochem. Biophys. Res. Commun. 1980, 95, 1722.

[41] E. C. King, W. J. Watkins, A. J. Blacker, T. D. H. Bugg, Journal of Polymer Science: Part A: Polymer Chemistry 1998, 36, 1995. 
Table 1

\begin{tabular}{lcc}
\hline Polymer & $\begin{array}{c}\text { PC/monomer molar } \\
\text { ratio in the feed }\end{array}$ & $\begin{array}{c}\text { PC/monomer molar ratio } \\
\text { in polymer (\%) NMR }\end{array}$ \\
& $(\%)$ & (IR) \\
\hline PGA(EO) $)_{3}$ PC 25 & 30 & $22 \pm 3$ \\
PGA(EO) $)_{3}$ PC 35 & 40 & $35 \pm 3(34 \pm 5)$ \\
PGA(EO) $)_{3}$ PC 80 & 120 & $83 \pm 5(85 \pm 3)$ \\
PGA(EO) $)_{4}$ PC & 38 & $15 \pm 2(18 \pm 5)$ \\
PAA(EO) $)_{3}$ PC & 26 & $25 \pm 3$ \\
PLL(EO) $)_{3}$ PC & 41 & $36 \pm 3$ \\
\hline
\end{tabular}




\section{Figure captions}

Figure 1. Target polymers and nomenclature

Figure 2. Synthetic scheme. Top: synthesis of $\mathrm{BOCNH}(\mathrm{EO})_{3} \mathrm{PC}$ and $\mathrm{Suc}(\mathrm{EO})_{3} \mathrm{PC}$ and bottom: coupling to the polyelectrolytes

Table 1. Preparation conditions and composition of the PC substituted polyelectrolytes.

Figure 3. $400 \mathrm{MHz}{ }^{1} \mathrm{H}-\mathrm{NMR}$ spectra of the unmodified polymers, the side chains and the polymers bearing PC moieties and assignment of signals for the latter. a) Spectra of (from top to bottom): PGA(EO) ${ }_{3} \mathrm{PC}$ with $\mathrm{DS}$ of 80 and $25 \%, \mathrm{BOCNH}(\mathrm{EO})_{3} \mathrm{PC}, \mathrm{PGA}$ and assignment of the signals according to $\mathrm{b}$. $\mathrm{b}$ ) Atom labelling for $\mathrm{PGA}(\mathrm{EO})_{3} \mathrm{PC}$. The same indexation from a to i holds also for BOCNH(EO) $)_{3}$ PC. c) Spectra of PLL(EO) $)_{3}$ PC, SucNH(EO) $)_{3}$ PC and PLL and the corresponding atom labeling (d).

Figure 4. IR spectra of $\mathrm{PGA}(\mathrm{EO})_{\mathrm{n}} \mathrm{PC}$ and $\mathrm{BOCNH}(\mathrm{EO})_{\mathrm{n}} \mathrm{PC}$ in $\mathrm{D}_{2} \mathrm{O}$. The spectrum of 4:0 $\mathrm{PC}$ (1,2-dibutyroyl-sn-glycero-3-phosphocholine) is given as reference. 


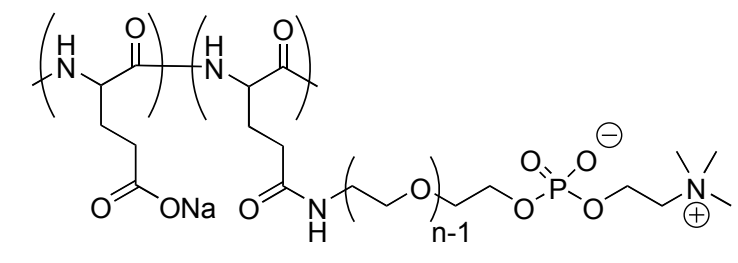

$\mathrm{n}=3, \mathrm{PGA}(\mathrm{EO})_{3} \mathrm{PC}$

$\mathrm{n}=4, \mathrm{PGA}(\mathrm{EO})_{4} \mathrm{PC}$
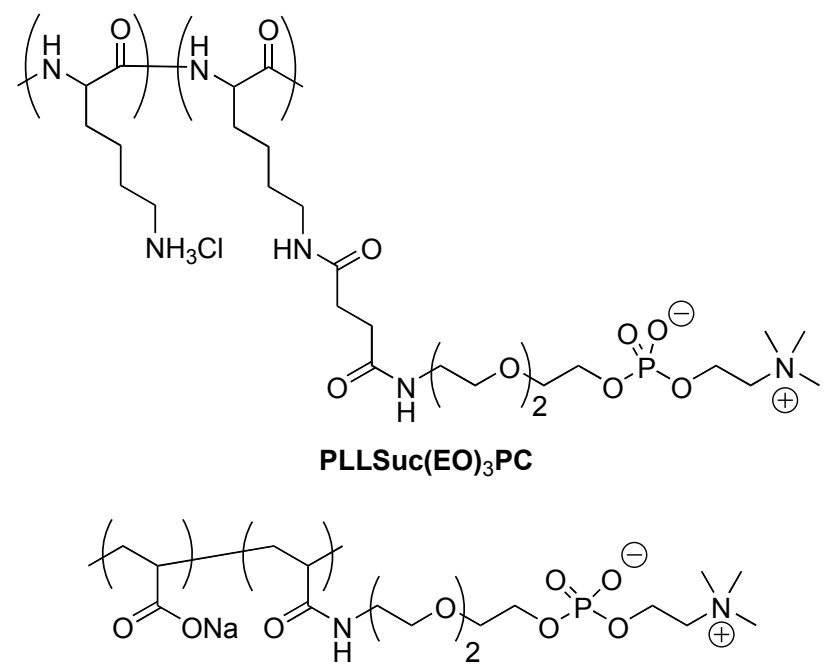

$\mathrm{PAA}(\mathrm{EO})_{3} \mathrm{PC}$

Figure 1 


$$
\begin{aligned}
& \mathrm{BOC}^{-\mathrm{N}} \overbrace{\mathrm{O}}^{\mathrm{H}} \stackrel{\text { 1) } \mathrm{POCl}_{3}, \mathrm{NEt}_{3}}{\longrightarrow} \\
& \text { 2) } \mathrm{HO}_{/}^{\oplus} \sim_{\mathrm{N}}^{\ominus} \mathrm{Ts}^{\ominus} \text {, pyr } \\
& \text { 3) } \mathrm{H}_{2} \mathrm{O}
\end{aligned}
$$<smiles>CC(CCOC(C)(C)CCOP(=O)([O-])OCC[N+](C)(C)C)NC(=O)OCc1ccccc1</smiles>

$$
\begin{aligned}
& \mathrm{n}=2, \mathrm{BOCNH}(\mathrm{EO})_{3} \mathrm{PC} \\
& \mathrm{n}=3, \mathrm{BOCNH}(\mathrm{EO})_{4} \mathrm{PC}
\end{aligned}
$$

1) $\mathrm{HCl}$

2)<smiles>O=C1CCC(=O)O1</smiles><smiles>CC(CCOP(=O)([O-])OCC[N+](C)(C)C)COCC(C)(C)NC(=O)CCC(=O)O</smiles>

\section{SucNH(EO) ${ }_{3} \mathrm{PC}$}

$$
\begin{aligned}
& \mathrm{BOCHN}(\mathrm{EO})_{n} \mathrm{PC} \stackrel{\mathrm{HCl}}{\longrightarrow} \mathrm{H}_{2} \mathrm{~N}(\mathrm{EO})_{n} \mathrm{PC} \\
& \mathrm{H}_{2} \mathrm{~N}(\mathrm{EO})_{n} \mathrm{PC} \underset{\mathrm{EDCl}, \mathrm{HOBt}}{\stackrel{\mathrm{PGA}}{\longrightarrow}} \mathrm{PGA}(\mathrm{EO})_{n} \mathrm{PC}
\end{aligned}
$$

SucHN(EO) $)_{3} \mathrm{PC} \underset{\mathrm{EDCl}, \mathrm{HOBt}}{\stackrel{\mathrm{PLL}}{\longrightarrow}} \mathrm{PLLSuc}(\mathrm{EO})_{3} \mathrm{PC}$ 

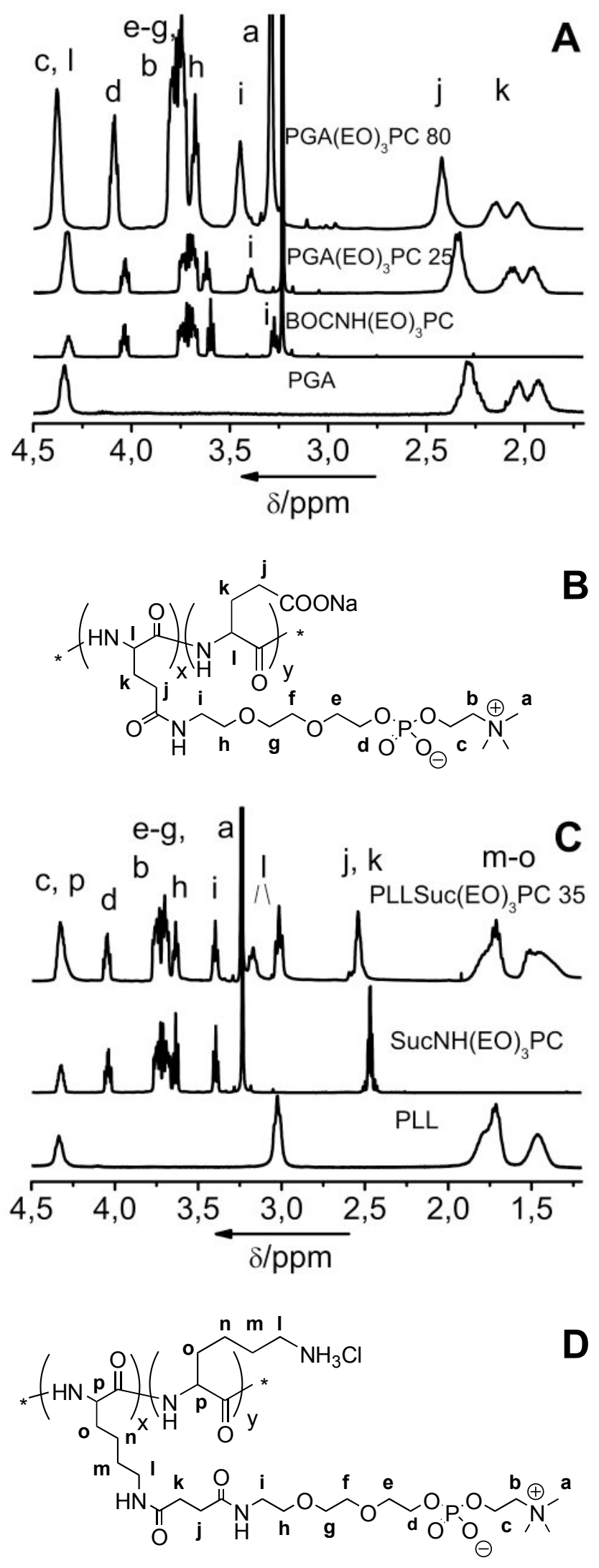

Figure 3 


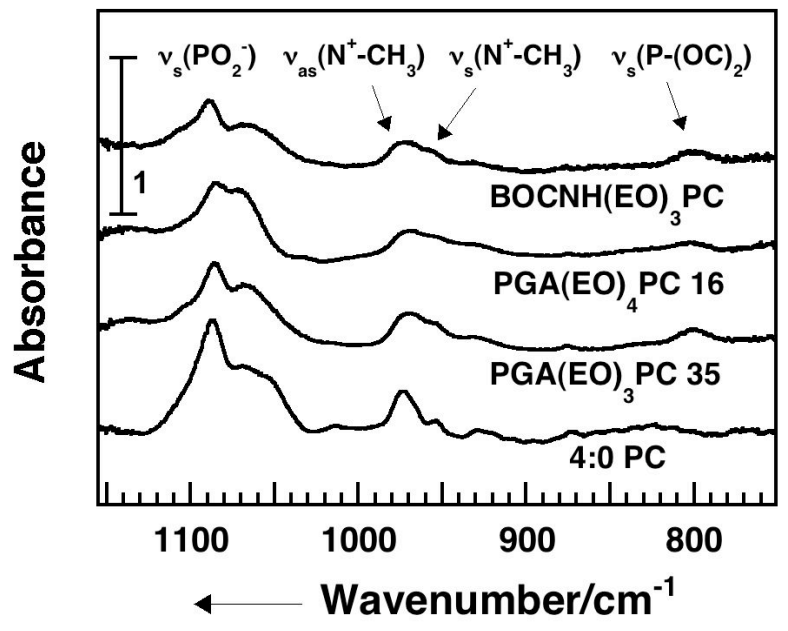

Figure 4 


\section{Table of Content}

Polyeletrolytes were modified with side-groups bearing zwitterionic phosphorylcholine groups (PC), known to impart protein repellent properties to biomaterials. Side groups containing PC and terminated either by an acid or an amine function can be synthesized at the scale of the gram. They can be readily condensed with polycations such as PLL or polyanions such as PGA or PAA. Degrees of substitution as high as $80 \%$ are obtained.
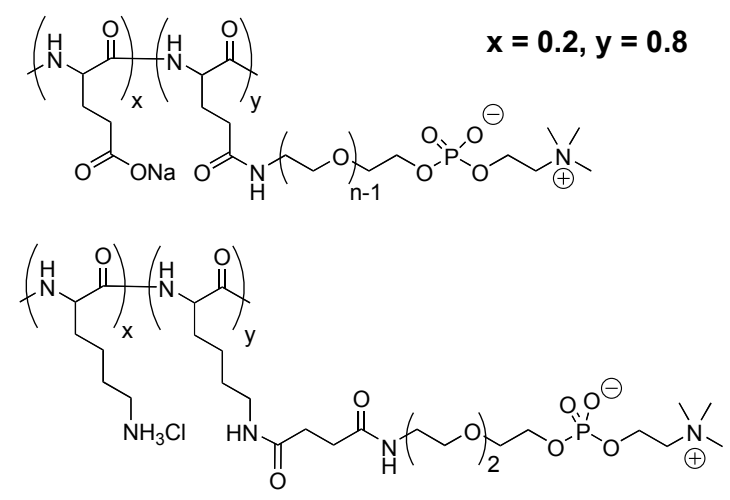


\section{Supplementary Information}

2-\{2-[2-(2-N-tertButoxycarbonylamino-ethoxy)-ethoxy]-ethoxy\}-ethylphosphorylcholine $\left(\mathbf{B O C N H}(\mathrm{EO})_{4} \mathbf{P C}\right)$ : the method described for $\mathrm{BOC}(\mathrm{EO})_{3} \mathrm{PC}$ was applied to $\mathrm{BOCNH}(\mathrm{EO})_{4} \mathrm{OH}(0.67 \mathrm{~g}, 2.29 \mathrm{mmol})$ as the starting material and afforded $\mathrm{BOCNH}(\mathrm{EO})_{4} \mathrm{PC}$ as a white powder $(0.59 \mathrm{~g}, 55 \%$ yield $)$.

${ }^{1} \mathrm{H}-\mathrm{NMR}\left(\mathrm{D}_{2} \mathrm{O}, 400 \mathrm{Mhz}\right) \delta=4.34\left(\mathrm{br} \mathrm{m}, 2 \mathrm{H}, \mathrm{POCH}_{2} \mathrm{CH}_{2} \mathrm{~N}\right), 4.06(\mathrm{br} \mathrm{m}, 2 \mathrm{H}$,

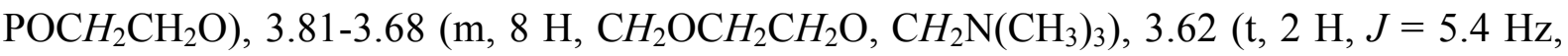
$\left.\mathrm{OCH}_{2} \mathrm{CH}_{2} \mathrm{~N}\right), 3.29\left(\mathrm{t}, 2 \mathrm{H}, J=5.4 \mathrm{~Hz}, \mathrm{CH}_{2} \mathrm{~N}\right), 3.26\left(\mathrm{~s}, 9 \mathrm{H}, \mathrm{N}\left(\mathrm{CH}_{3}\right)_{3}\right), 1.47\left(\mathrm{~s}, 9 \mathrm{H}, \mathrm{C}\left(\mathrm{CH}_{3}\right)_{3}\right)$. ${ }^{13} \mathrm{C}-\mathrm{NMR}\left(\mathrm{D}_{2} \mathrm{O}, 100 \mathrm{Mhz}\right): \delta=158.8(\mathrm{CO}), 81.6\left(C\left(\mathrm{CH}_{3}\right)_{3}\right), 70.8(\mathrm{~d}, J=7.7 \mathrm{~Hz}$, $\left.\mathrm{POCH}_{2} \mathrm{CH}_{2} \mathrm{O}\right), 70.4,70.3,70.3,70.1,\left(\mathrm{OCH}_{2} \mathrm{CH}_{2}\right), 66.7\left(\mathrm{~m}, \mathrm{CH}_{2} \mathrm{~N}\left(\mathrm{CH}_{3}\right)_{3}\right), 65.5(\mathrm{~d}, J=5.9$ $\left.\mathrm{Hz}, \mathrm{POCH}_{2} \mathrm{CH}_{2} \mathrm{O}\right), 60.1\left(\mathrm{~d}, J=5.1 \mathrm{~Hz}, \mathrm{POCH}_{2} \mathrm{CH}_{2} \mathrm{~N}\right), 54.7\left(\mathrm{t}, J=3.9 \mathrm{~Hz}, \mathrm{~N}\left(\mathrm{CH}_{3}\right)_{3}\right), 40.3$ $\left(\mathrm{CH}_{2} \mathrm{~N}\right), 28.4\left(\mathrm{C}\left(\mathrm{CH}_{3}\right)_{3}\right.$. IR (ATR) $v_{\max }: 3365,3240(v \mathrm{NH}), 2977\left(v \mathrm{CH}_{3}\right), 2935\left(v_{\mathrm{as}} \mathrm{CH}_{2}\right)$, $2874\left(v_{\text {as }} \mathrm{CH}_{2}\right), 1689$ (amide I ), 1522 (amide II), $1482\left(\delta_{\text {as }}\left(\mathrm{CH}_{3}\right)_{3} \mathrm{~N}^{+}\right), 1455,1419,1366(\delta$ $\left.\mathrm{CH}_{3}\right), 1238,1137,1086\left(v_{\mathrm{s}} \mathrm{PO}_{2}^{-}\right), 1058,970,953\left(v_{\text {as }}\left(\mathrm{CH}_{3}\right)_{3} \mathrm{~N}^{+}\right), 925,875,781 \mathrm{~cm}^{-1}$.

\section{PGA(EO) ${ }_{3}$ PC 35 :}

${ }^{1} \mathrm{H}-\mathrm{NMR}\left(\mathrm{D}_{2} \mathrm{O}, 400 \mathrm{MHz}\right): \delta=4.34\left(\right.$ broad s, $\left.\mathrm{POCH}_{2} \mathrm{CH}_{2} \mathrm{~N}, \mathrm{NHCHCO}\right), 4.05$ (broad m,

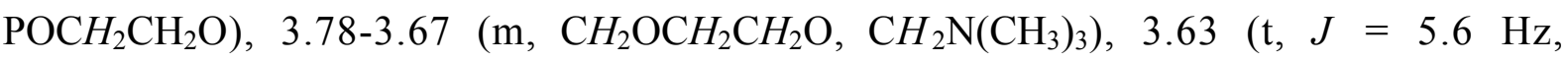
$\left.\mathrm{OCH}_{2} \mathrm{CH}_{2} \mathrm{~N}\right), 3.40\left(\mathrm{t}, \mathrm{J}=5.6 \mathrm{~Hz}, \mathrm{CH}_{2} \mathrm{~N}\right), 3.24\left(\mathrm{~s}, \mathrm{~N}\left(\mathrm{CH}_{3}\right)_{3}, 2.33\left(\right.\right.$ broad s, $\left.\mathrm{CH}_{2} \mathrm{CO}\right), 2.07$ (broad s, $\left.\mathrm{CHCH}_{2} \mathrm{CH}_{2}\right), 1.97$ (broad s, $\left.\mathrm{CHCH}_{2} \mathrm{CH}_{2}\right) \cdot{ }^{13} \mathrm{C}-\mathrm{NMR}\left(\mathrm{D}_{2} \mathrm{O}, 100 \mathrm{MHz}\right): \delta=180.6$ (CO), 175.5 (CO), 174.2 (CO), $173.8(C \mathrm{O}), 70.7$ (d, $J=7.7 \mathrm{~Hz}, \mathrm{POCH}_{2} \mathrm{CH}_{2}$ ), 70.3, 70.1, 69.4, $\left(\mathrm{OCH}_{2} \mathrm{CH}_{2}\right), 66.6\left(\mathrm{~m}, \mathrm{CH}_{2} \mathrm{~N}\left(\mathrm{CH}_{3}\right)_{3}\right), 65.5\left(\mathrm{~d}, J=5.5, \mathrm{POCH}_{2} \mathrm{CH}_{2} \mathrm{O}\right), 60.1(\mathrm{~d}, J=4.5$ $\left.\mathrm{Hz}, \mathrm{POCH}_{2} \mathrm{CH}_{2} \mathrm{~N}\right), 54.6\left(\mathrm{t}, J=3.7 \mathrm{~Hz}, \mathrm{~N}\left(\mathrm{CH}_{3}\right)_{3}\right), 54.1(\mathrm{CH}), 53.7(\mathrm{CH}), 39.5\left(\mathrm{CH}_{2} \mathrm{~N}\right), 33.2$ 
$\left(\mathrm{CH}_{2} \mathrm{CO}\right), 32.4\left(\mathrm{CH}_{2} \mathrm{CO}\right), 28.05\left(\mathrm{CHCH}_{2} \mathrm{CH}_{2}\right), 27.8\left(\mathrm{CHCH}_{2} \mathrm{CH}_{2}\right)$. IR (sol. $\left.\mathrm{D}_{2} \mathrm{O}\right) v_{\max }: 3406$, 1697 ( v COO), 1645 (amide I ), 1566 (amide II), 1458, 1404, 1366, $1086\left(v_{\mathrm{s}} \mathrm{PO}_{2}{ }^{-}\right), 1064$, $973,953\left(v_{\text {as }}\left(\mathrm{CH}_{3}\right)_{3} \mathrm{~N}^{+}\right), 799 \mathrm{~cm}^{-1}$.

PGA(EO) ${ }_{4}$ PC 16 : this compound is synthesized as described above for PGA(EO) ${ }_{3}$ PC with PGA (153 mg, $1.01 \mathrm{mmol}$ of monomer units) and BOCNH(EO) ${ }_{4} \mathrm{PC}(179 \mathrm{mg}, 0.39 \mathrm{mmol}, 0.38$ equiv.) . $\mathrm{PGA}(\mathrm{EO})_{4} \mathrm{PC} 16$ is obtained as a very hygroscopic white powder (150 mg, yield 71\%): ${ }^{1} \mathrm{H}$ NMR $\left(\mathrm{D}_{2} \mathrm{O}\right): \delta=4.33$ (broad s, $\left.\mathrm{POCH}_{2} \mathrm{CH}_{2} \mathrm{~N}, \mathrm{NHCHCO}\right), 4.03$ (broad m, $\left.\mathrm{POCH}_{2} \mathrm{CH}_{2} \mathrm{O}\right), 3.80-3.66\left(\mathrm{~m}, \mathrm{CH}_{2} \mathrm{OCH}_{2} \mathrm{CH}_{2} \mathrm{O}, \mathrm{CH}_{2} \mathrm{~N}\left(\mathrm{CH}_{3}\right)_{3}\right), 3.61(\mathrm{t}, \mathrm{J}=5.58 \mathrm{~Hz}$, $\left.\mathrm{OCH}_{2} \mathrm{CH}_{2} \mathrm{~N}\right), 3.39$ (broad s, $\left.\mathrm{CH}_{2} \mathrm{~N}\right), 3.22\left(\mathrm{~s}, \mathrm{~N}\left(\mathrm{CH}_{3}\right)_{3}\right), 2.37$ (broad s, $\left.\mathrm{CH}_{2} \mathrm{CO}\right), 2.07$ (broad s, $\mathrm{CHCH}_{2} \mathrm{CH}_{2}$ ), 1.97 (broad s, $\left.\mathrm{CHCH}_{2} \mathrm{CH}_{2}\right) .{ }^{13} \mathrm{C}$ NMR $\left(\mathrm{D}_{2} \mathrm{O}\right): \delta=180.6(\mathrm{CO}), 175.5(\mathrm{CO})$, $174.2(\mathrm{CO}), 173.8(\mathrm{CO}), 70.7\left(\mathrm{~d}, \mathrm{~J}=7.63 \mathrm{~Hz}, \mathrm{POCH}_{2} \mathrm{CH}_{2} \mathrm{O}\right), 70.3,70.2,70.1,69.5$ $\left(\mathrm{OCH}_{2} \mathrm{CH}_{2}\right), 66.7\left(\mathrm{~m}, \mathrm{CH}_{2} \mathrm{~N}\left(\mathrm{CH}_{3}\right)_{3}\right), 65.6\left(\mathrm{~d}, \mathrm{~J}=5.41 \mathrm{~Hz}, \mathrm{POCH}_{2} \mathrm{CH}_{2} \mathrm{O}\right), 60.1(\mathrm{~d}, J=5.11 \mathrm{~Hz}$, $\left.\mathrm{POCH}_{2} \mathrm{CH}_{2} \mathrm{~N}\right), 56.4($ broad s, $\mathrm{CH}), 54.7\left(\mathrm{t}, \mathrm{J}=3.63 \mathrm{~Hz}, \mathrm{~N}\left(\mathrm{CH}_{3}\right)_{3}\right), 39.6\left(\mathrm{CH}_{2} \mathrm{~N}\right), 32.4$ $\left(\mathrm{CH}_{2} \mathrm{CO}\right), 32.0\left(\mathrm{CH}_{2} \mathrm{CO}\right), 26.2\left(\right.$ broad s, $\left.\mathrm{CHCH}_{2} \mathrm{CH}_{2}\right)$. IR (sol. $\left.\mathrm{D}_{2} \mathrm{O}\right) v_{\max }: 3406,1697$ (v COO), 1644 (amide I ), 1564 (amide II), $1482\left(\delta_{\text {as }}\left(\mathrm{CH}_{3}\right)_{3} \mathrm{~N}^{+}\right), 1463,1447,1405,1086\left(v_{\mathrm{s}}\right.$ $\left.\mathrm{PO}_{2}^{-}\right), 1066,972,956\left(v_{\text {as }}\left(\mathrm{CH}_{3}\right)_{3} \mathrm{~N}^{+}\right), 798 \mathrm{~cm}^{-1}$.

PAA(EO) ${ }_{3}$ PC 25 : this compound is synthesized as described above for PGA(EO)3PC 35 with PAA (77 mg, $1.06 \mathrm{mmol}$ of monomer units) and $\mathrm{BOCNH}(\mathrm{EO}){ }_{3} \mathrm{PC}(110 \mathrm{mg}, 0.27 \mathrm{mmol}$, 0.25 equiv.) as the starting materials. Pure $\mathrm{PAA}(\mathrm{EO}){ }_{3} \mathrm{PC} 25$ is obtained as a white powder (126 mg, 82\% yield). ${ }^{1} \mathrm{H}$ NMR $\left(\mathrm{D}_{2} \mathrm{O}, 400 \mathrm{Mhz}\right): \delta=4.32\left(\right.$ broad s, $\left.\mathrm{POCH}_{2} \mathrm{CH}_{2} \mathrm{~N}, \mathrm{CH}_{2} \mathrm{CH}\right)$, 4.03 (broad m, $\mathrm{POCH}_{2} \mathrm{CH}_{2} \mathrm{O}$ ), 3. 79-3. 65 (m, $\left.\mathrm{CH}_{2} \mathrm{OCH}_{2} \mathrm{CH}_{2} \mathrm{O}, \mathrm{CH}_{2} \mathrm{~N}\left(\mathrm{CH}_{3}\right)_{3}\right), 3.60$ (broad s), 3.37 (broad s, $\left.\mathrm{CH}_{2} \mathrm{~N}\right), 3.23\left(\mathrm{~s}, \mathrm{~N}\left(\mathrm{CH}_{3}\right)_{3}\right), 2.22$ (broad s), 2.08 (broad s), 1.74 (broad s), 1.57 (broad s), $\left(\mathrm{CH}_{2} \mathrm{CH}\right) .{ }^{13} \mathrm{C}$ NMR $\left(\mathrm{D}_{2} \mathrm{O}, 100 \mathrm{Mhz}\right): \delta=182.0(\mathrm{CO}), 181.8(\mathrm{CO}), 177.3(\mathrm{CO})$, $70.1\left(\mathrm{~d}, J=7.7 \mathrm{~Hz}, \mathrm{POCH}_{2} \mathrm{CH}_{2} \mathrm{O}\right), 69.7,69.5,68.8,\left(\mathrm{OCH}_{2} \mathrm{CH}_{2}\right), 65.9\left(\mathrm{~m}, \mathrm{CH}_{2} \mathrm{~N}\left(\mathrm{CH}_{3}\right)_{3}\right), 64.9$ 
$\left(\mathrm{d}, J=5.1 \mathrm{~Hz}, \mathrm{POCH}_{2} \mathrm{CH}_{2} \mathrm{O}\right), 59.4\left(\mathrm{~d}, J=4.8 \mathrm{~Hz}, \mathrm{POCH}_{2} \mathrm{CH}_{2} \mathrm{~N}\right), 54.0$ (t, $J=3.3 \mathrm{~Hz}$, $\mathrm{N}\left(\mathrm{CH}_{3}\right)_{3}, 44.0$ (broad s), 42.6 (broad s), 38.8 (broad s), 36.1 (broad s) $\left(\mathrm{CH}_{2} \mathrm{CH}\right)$.

\section{PLLSuc(EO) $)_{3}$ PC 35:}

${ }^{1} \mathrm{H}-\mathrm{NMR}\left(\mathrm{D}_{2} \mathrm{O}, 400 \mathrm{MHz}\right): \delta=4.33\left(\right.$ broad s, $\left.\mathrm{POCH}_{2} \mathrm{CH}_{2} \mathrm{~N}, \mathrm{CH}_{2} \mathrm{CH}\right), 4.05$ (broad m, POCH $\mathrm{CH}_{2} \mathrm{O}$ ), 3. 78 -3. 67 (broad m, $\left.\mathrm{CH}_{2} \mathrm{OCH}_{2} \mathrm{CH}_{2} \mathrm{O}, \mathrm{CH}_{2} \mathrm{~N}\left(\mathrm{CH}_{3}\right)_{3}\right), 3.64$ (t, $J=5.3 \mathrm{~Hz}$, $\left.\mathrm{OCH}_{2} \mathrm{CH}_{2} \mathrm{~N}\right), 3.25\left(\mathrm{~s}, \mathrm{~N}\left(\mathrm{CH}_{3}\right)_{3}\right), 3.40\left(\mathrm{t}, J=5.3 \mathrm{~Hz}, \mathrm{OCH}_{2} \mathrm{CH}_{2} \mathrm{NHCO}\right), 3.17\left(\mathrm{~m}, \mathrm{CH}_{2} \mathrm{NHCO}\right)$, $3.02\left(\mathrm{t}, J=7.11 \mathrm{~Hz}, \mathrm{CH}_{2} \mathrm{NH}_{2}\right), 2.54$ (broad s, $\left.\mathrm{COCH}_{2} \mathrm{CH}_{2} \mathrm{CO}\right), 1.72$ (broad m), $\left(\mathrm{CHCH}_{2} \mathrm{CH}_{2} \mathrm{CH}_{2} \mathrm{CH}_{2} \mathrm{~N}\right), 1.49$ (broad m). ${ }^{13} \mathrm{C}-\mathrm{NMR}\left(\mathrm{D}_{2} \mathrm{O}, 100 \mathrm{MHz}\right): \delta=174.5(\mathrm{CO}), 173.7$ (CO), 173.5 (CO), 70.1 (d, $\left.J=7.8 \mathrm{~Hz}, \mathrm{OCH}_{2} \mathrm{CH}_{2} \mathrm{OP}\right)$, 69.7, 69.4, 68.8, $\left(\mathrm{OCH}_{2} \mathrm{CH}_{2}\right), 66.0$ (m, $\left.\mathrm{CH}_{2} \mathrm{~N}\left(\mathrm{CH}_{3}\right)_{3}\right), 64.9\left(\mathrm{~d}, J=5.9 \mathrm{~Hz}, \mathrm{POCH}_{2} \mathrm{CH}_{2} \mathrm{O}\right), 59.4\left(\mathrm{~d}, J=4.78 \mathrm{~Hz}, \mathrm{POCH}_{2} \mathrm{CH}_{2} \mathrm{~N}\right), 54.0$ $\left(\mathrm{t}, J=3.81 \mathrm{~Hz}, \mathrm{~N}\left(C \mathrm{H}_{3}\right)_{3}\right), 53.4(C \mathrm{H}), 39.2\left(\mathrm{CH}_{2} \mathrm{NH}_{2}\right), 39.1\left(C \mathrm{H}_{2} \mathrm{NHCO}\right), 39.0$ $\left(\mathrm{OCH}_{2} \mathrm{CH}_{2} \mathrm{NHCO}\right), \quad 31.2,31.2, \quad\left(\mathrm{COCH}_{2} \mathrm{CH}_{2} \mathrm{CO}\right), \quad 30.6,27.9,26.5,22.4,22.2$, $\left(\mathrm{CHCH}_{2} \mathrm{CH}_{2} \mathrm{CH}_{2} \mathrm{CH}_{2} \mathrm{~N}\right)$. 


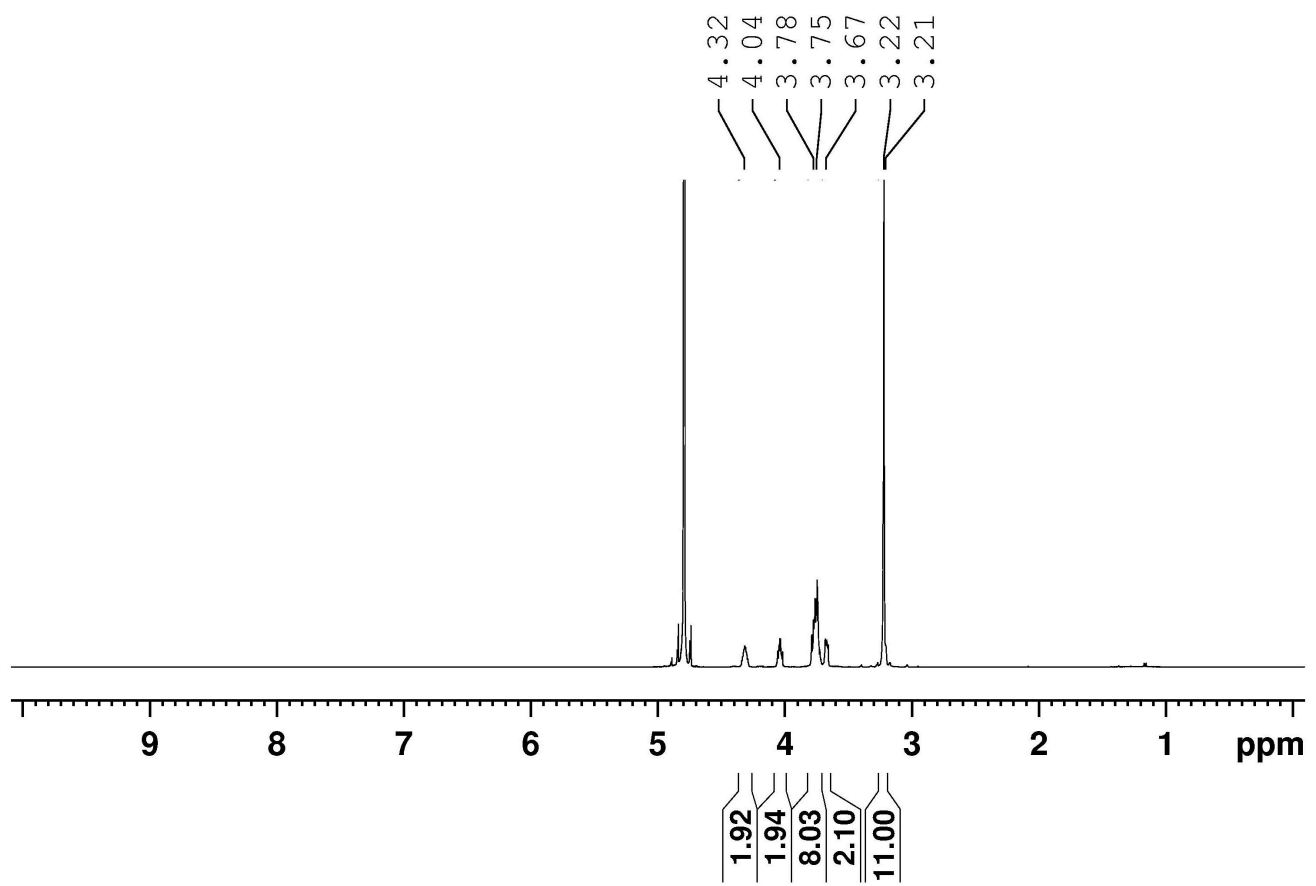

Figure S1. Spectrum of crude $\mathrm{PC}(\mathrm{EO})_{3} \mathrm{NH}_{3} \mathrm{Cl}$.

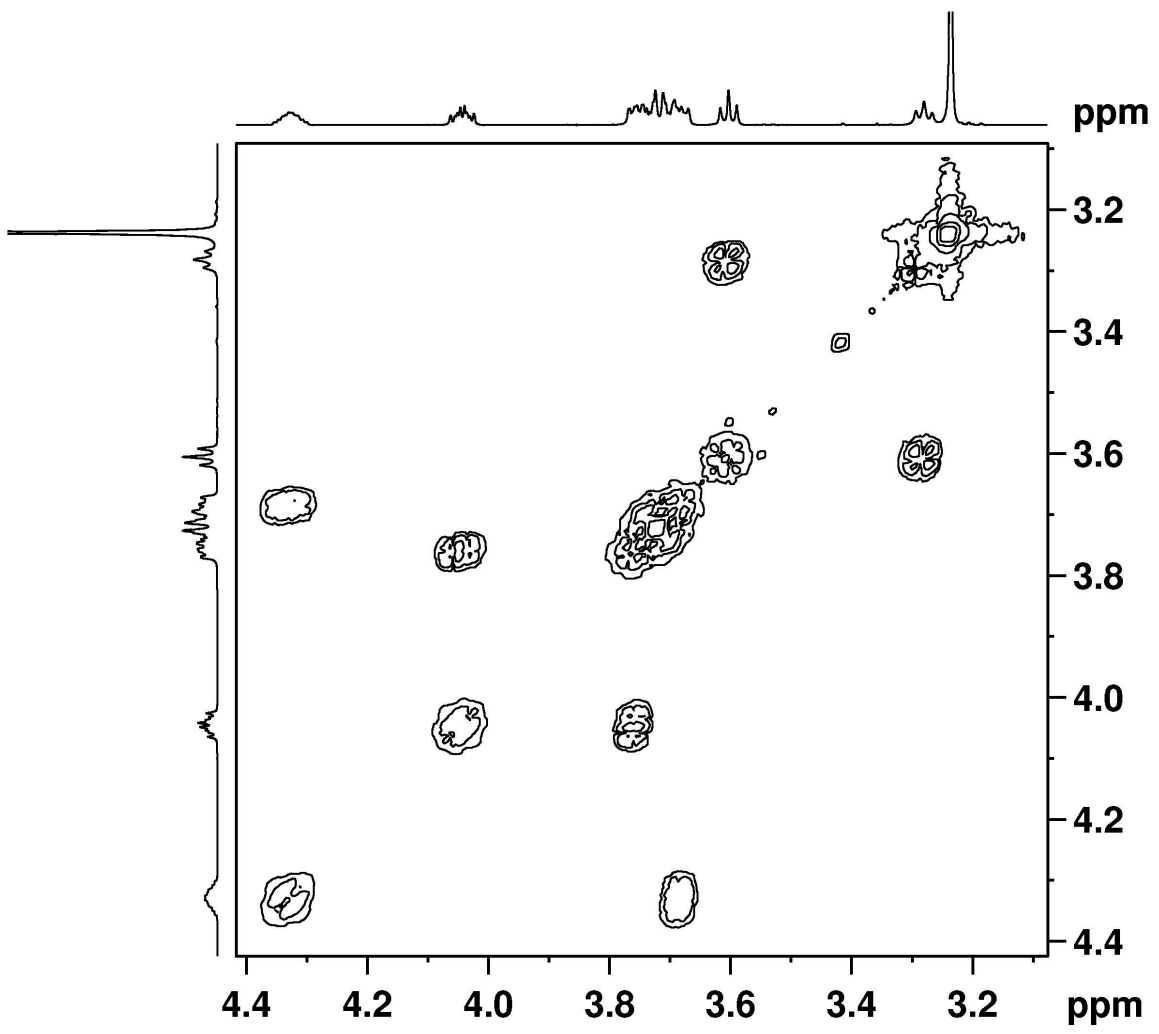

Figure S2. section of the COSY spectrum of $\mathrm{BOCNH}(\mathrm{EO})_{3} \mathrm{PC}$. 


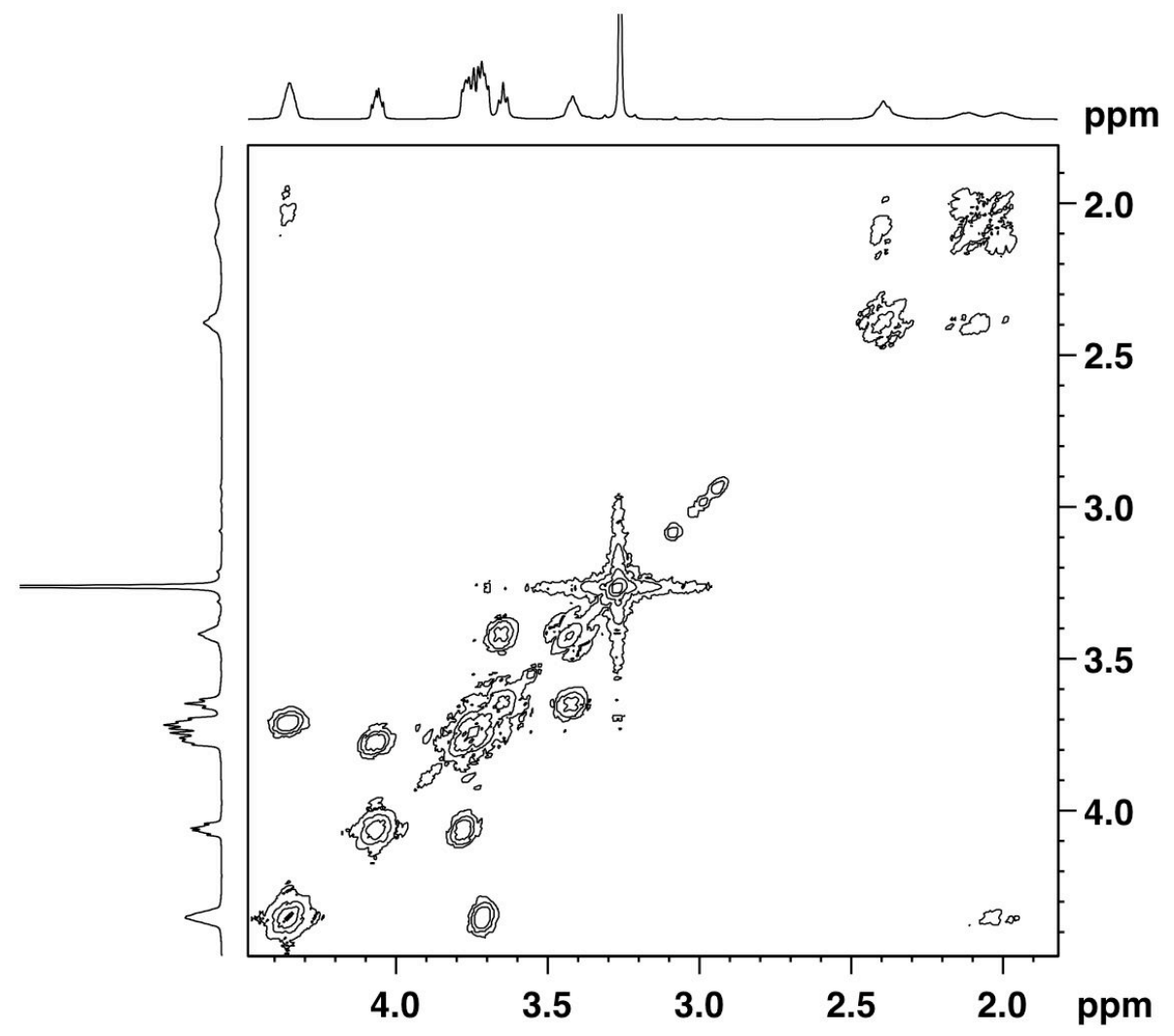

Figure S3a. COSY spectrum of PGA(EO) $)_{3}$ PC 80.

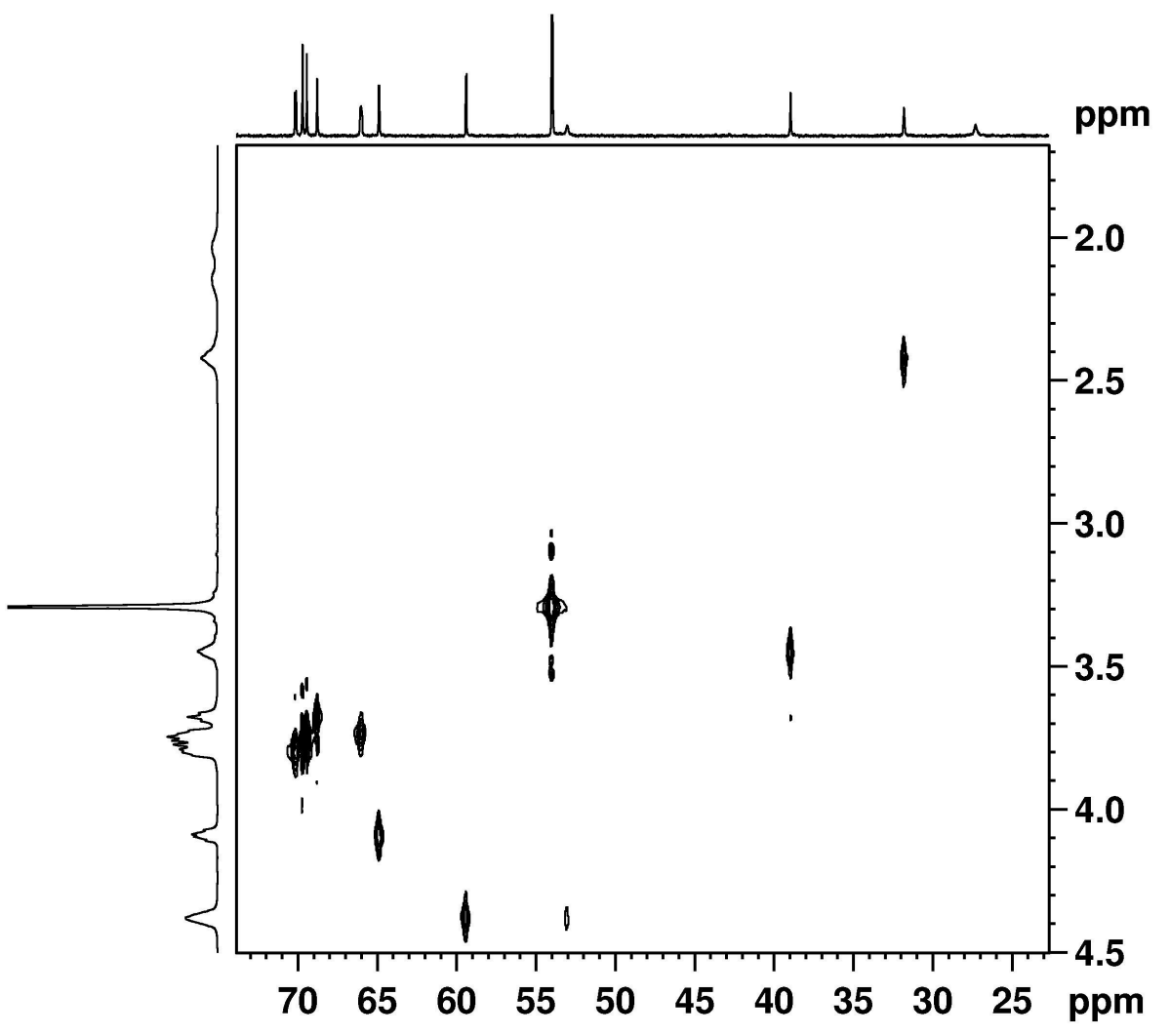

Figure S3b. ${ }^{1} \mathrm{H}-{ }^{13} \mathrm{C}$ correlation spectrum of $\mathrm{PGA}(\mathrm{EO}){ }_{3} \mathrm{PC} 80$ 


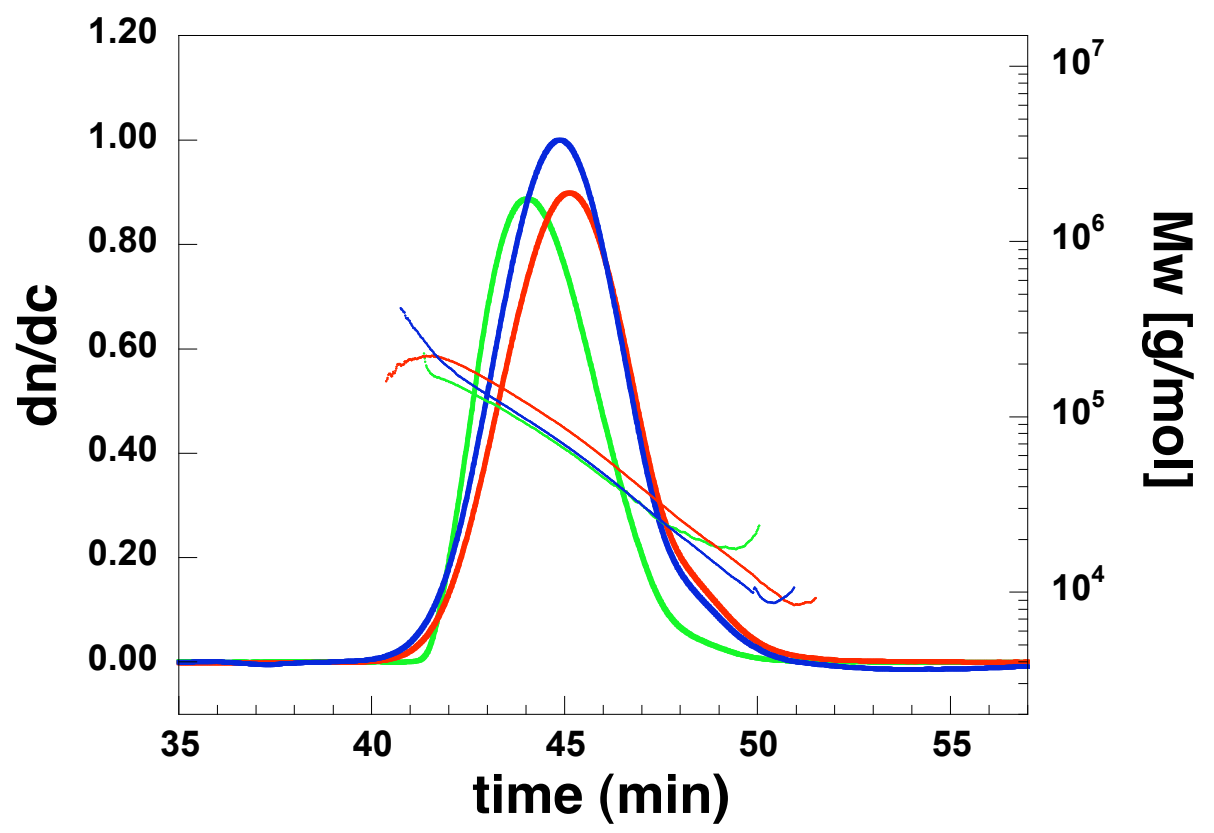

Figure S4. SEC measurements. Green: PGA; blue PGA(EO) $)_{4} \mathrm{PC} 16$; red: PGA(EO) ${ }_{3} \mathrm{PC} 35$. 